Vol. 23, No. 4, pp. 407 416, 2020.

\title{
Organic/Inorganic Hybrid Moisture Permeation Barrier Films for Back-sheet of Silicon Photovoltaic Modules
}

\author{
Dongwook Jung, Eunjin Jang, and Sangwoo Ryu ${ }^{\dagger}$
}

Department of Advanced Materials Engineering, Kyonggi University, Suwon 16227, Republic of Korea

\section{실리콘 태양전지 모듈용 백시트의 유무기 하이브리드 투습방지막 연구}

\author{
정동욱, 장은진, 유상우 ${ }^{\dagger}$ \\ 경기대학교 신소재공학과
}

(Received November 17 2020; Revised December 7 2020; Accepted December 10)

\begin{abstract}
s
In the crystalline silicon-based photovoltaic system, Si solar cells are connected in series and high voltage larger than $1000 \mathrm{~V}$ is applied between module frames and cells during the operation. This can generate a leakage current through the modules and the loss of efficiency and output power called potential-induced degradation (PID) occurs. When the $\mathrm{c}-\mathrm{Si}$ solar cell module is exposed to a high-temperature, high-humidity environment, water molecules penetrates through the back sheet of the module and EVA is corroded, which accelerates PID. Various methods to prevent the permeation of water molecules have been widely investigated. Here we propose organic/inorganic hybrid coatings that can provide high mechanical flexibility as well as low water vapor transmission rate (WVTR). Silamer, a Silane-based inorganic / organic hybrid polymer, flattens the surface of the commercial back sheet and $\mathrm{Al}_{2} \mathrm{O}_{3}$ grown on top of it suppresses the moisture permeation. Additional coating of the organic layer on $\mathrm{Al}_{2} \mathrm{O}_{3}$ shows the lowest WVTR of 0.36 .
\end{abstract}

Key words: silicon solar cell, moisture barrier, potential-induced degradation, organic/inorganic hybrid coatings

${ }^{\dagger}$ Corresponding Author: Sangwoo Ryu

E-mail: sryu@kgu.ac.kr 


\section{1. 서론}

고갈자원인 화석 연료에 대한 의존성이 높은 현대사 회에서 최근 이상기후 현상 및 지구온난화 문제가 전 세 계적으로 크게 대두되면서 친환경-신재생 에너지원으 로의 태양광 발전에 대한 관심이 최고조에 이르고 있다. 차기 미국 대통령으로 당선이 유력시 되고 있는 조 바 이든 미국 대통령 후보가 '2050 탄소중립'을 목표로 내 세우면서, 2 조 달러를 태양광 등 친환경 에너지 인프라 를 구축하는데 투입하겠다고 공약함에 따라, 국내에서 도 저탄소 녹색 경제 체제로의 전환을 위한 '그린 뉴딜' 에 8조원을 추가 지원하기로 하는 등 향후 태양광 시장 은 국내외적으로 더욱 확대될 것으로 예상된다. ${ }^{1)}$ 태양 광 발전은 지속가능한 친환경 에너지로 무한한 태양광 을 에너지원으로 하며, 높은 신뢰성을 갖는다는 장점이 있다. 그러나 태양전지는 습기에 의해서 열화되어 효율 이 감소하는 문제가 있다. 특히, 태양전지 후면의 백시 트를 통해 수분이 침투할 경우 투과된 수분이 봉지재로 사용되는 EVA (Ethylene Vinyl Acetate)로 침투하여 전기 전도도를 증가시키고, 결국 누설 전류가 발생하여 효율이 감소하게 된다. ${ }^{2}{ }^{2}$ 이러한 문제는 고온, 다습한 가 혹한 환경에 노출될 경우 가속되며, 투습에 의한 EVA의 부식문제 역시 피할 수 없다. 태양전지 봉지재를 저항성 이 높은 high- $\rho$ EVA나 폴리올레핀 (POE, Polyolefin elastomer)으로 대체하면 투습에 의한 효율 감소를 방
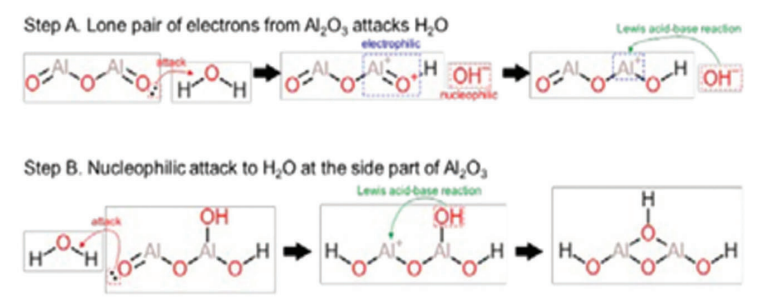

Step C. Chemical reaction between pseudo-boehmite

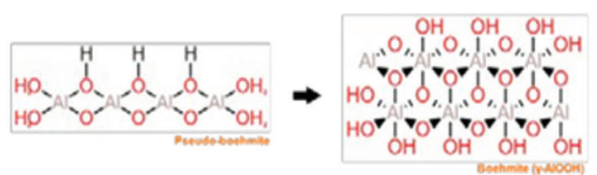

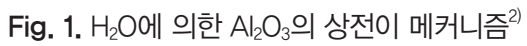

지할 수 있다고 알려져 있으나, 비용 증가가 수반되고 $\mathrm{POE}$ 의 경우 $\mathrm{EVA}$ 비해 융점이 높아 추가적으로 라미네 이션 공정 최적화가 필요한 한계가 있다. ${ }^{3-5)}$ 투습도를 감소시키기 위한 다른 방법으로는 이를 방지할 수 있는 barrier 층을 삽입하는 것으로 $\mathrm{SnO}_{\mathrm{x}}, \mathrm{SiN}_{\mathrm{x}}, \mathrm{TiO}_{2}, \mathrm{Al}_{2} \mathrm{O}_{3}$ 와 같은 물질들이 우수한 투습 방지 특성을 나타냈다고 보고되었다. 그 중에서도 $\mathrm{Al}_{2} \mathrm{O}_{3}$ 는 공정최적화가 잘 되 어있고 저렴하며, 우수한 투습 방지 특성을 지닌 것으로 잘 알려져 있으나, 고온 고습의 가혹한 환경에 노출될 경우 Fig. 1 과 같이 가수분해를 통해 결정질의 boehmite 로 상전이 하면서 부피가 팽창하고, 결정 내 입계를 통 해 수분이 침투될 수 있다고 보고되었다. ${ }^{6,7)}$ 따라서 투습 방지막으로 $\mathrm{Al}_{2} \mathrm{O}_{3}$ 를 사용하기 위해서 또 다른 산화물이 나 유기층과 함께 다층구조를 만듦으로써 $\mathrm{Al}_{2} \mathrm{O}_{3}$ 의 부식 저항성을 향상시킨 연구가 진행되었다. ${ }^{89)}$ 그 중 Silane 기반의 유무기 하이브리드 폴리머(silamer)와 $\mathrm{Al}_{2} \mathrm{O}_{3}$ 를 다층구조로 적용하여 환경 안정성을 향상시키고 두 층 의 시너지를 통해 투습 방지 특성을 향상시킨 연구 결과 가 보고되기도 하였다. ${ }^{8)}$ 본 연구에서는 태양전지 후면 백시트에 silamer $/ \mathrm{Al}_{2} \mathrm{O}_{3} /$ silamer 구조의 유무기 하이브 리드 코팅을 적용하여 투습도를 측정하고 비교함으로써 유기층인 silamer의 효과를 확인하였다. 그 결과 약 60 $\mathrm{nm}$ 두께의 비정질 $\mathrm{Al}_{2} \mathrm{O}_{3}$ 와 $3 \mu \mathrm{m}$ 두께의 silamer 층을 반복 적용하는 경우 투습 방지 효과가 매우 향상되었다.

\section{2. 태양전지 모듈에서의 PID (potential-induced degradation) 열화 발생}

국내 태양광 발전소에 설치된 PERC 태양전지 모듈 은 목표로 하는 전압 시스템을 구성하기 위해 직렬로 연 결되며, 태양광 발전 시스템의 발전 전압이 직렬 연결 된 모듈의 개수에 비례하여 모듈 프레임과 태양전지 사 이에 고전압이 인가되고 누설 전류가 발생한다. ${ }^{2}$ 이처럼 인가된 고전압에 의한 태양전지의 효율 및 최대 출력의 급격한 저하를 Potential-Induced degradation (PID) 라고 한다. $\mathrm{PID}$ 는 고온 다습한 환경일수록 빈번하게 발 생하고, 태양 전지 후면의 수분 침투에 의해 $\mathrm{EVA}$ 의 전 


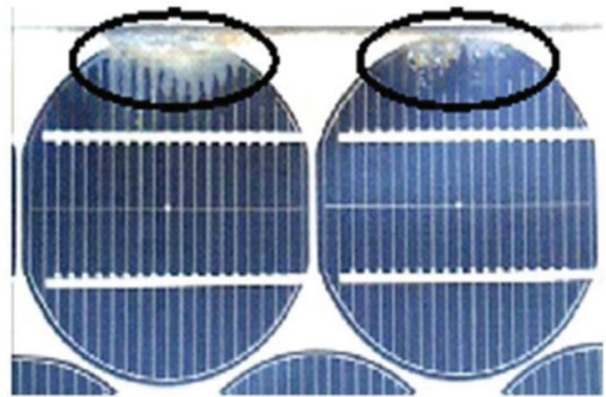

Fig. 2. 수분 침투에 의한 PV 모듈의 EVA와 백시트 사이 계면 박리 ${ }^{13)}$

기 전도도 상승을 유발하여 누설 전류를 증가시킨다. 습 도 증가에 따른 수분 침투는 주로 태양전지 모듈 하단부 의 백시트를 통해 이루어지며, 높은 온도에서 투과된 수 분은 $\mathrm{EVA}$ 를 부식시켜 추가적인 태양전지 모듈 성능 저 하를 발생시킨다. ${ }^{10-12)}$ 수분이 침투할 경우 Fig. 2와 같 이 EVA와 백시트 사이의 계면에서 박리가 발생하고, 이 는 태양전지 모듈 모서리에서 가장 많이 일어난다. 박리 는 더 많은 양의 수분 침투를 허용하며, 직렬저항의 증 가로 이어져 결국 출력 저하를 유발한다. 앞서 언급했듯 이, 습도와 온도 상승은 $\mathrm{EVA}$ 의 화학적 분해를 일으키 며 이때 아세트산과 더불어 기타 휘발성 가스가 생성된 다. ${ }^{13,14)} \mathrm{EVA}$ 와 후면 백시트 사이에 생성된 아세트산은 쉽게 빠져나가지 못하고 태양전지 모듈 내에서 여러 가 지 열화 반응의 원인으로 작용한다. 먼저, 아세트산은 $\mathrm{EVA}$ 의 접착력 손실에 의한 박리를 유도하고 $\mathrm{EVA}$ 의 분 해 반응을 향상시키는 자가 촉매 작용을 한다. ${ }^{13,14)}$ 둘째 로, 금속 물질 및 금속 배선 연결 부위를 부식시킴으로 써 직렬저항의 증가를 유발하고 태양전지 모듈의 효율 이 감소한다. ${ }^{14)}$ 이처럼 수분은 태양전지 모듈의 출력 및 효율 저하를 유발하는 요인으로 작용하며, 따라서 태양 전지의 장기 신뢰성을 확보하기 위해 투습을 방지하기 위한 다양한 연구가 진행되었다.

\section{3. 투습방지 연구동향}

\section{3-1. 투습방지 대체재}

\section{3-1-1. high- $\rho E A^{(5)}$}

Ionomer, 고품질 EVA, 열가소성 폴리올레핀과 같 은 높은 비저항( $\rho)$ 을 갖는 고분자 필름을 사용하면 PID 를 방지할 수 있다고 보고되었다. Virtuani 등은 현재 제조된 대부분의 모듈이 $\mathrm{EVA}$ 를 봉지재로 사용하고 있 어 $\mathrm{EVA}$ 의 비저항에 따른 $\mathrm{PID}$ 저감 효과에 대해 집중적 으로 연구하였다. $60{ }^{\circ} \mathrm{C} / 85 \% \mathrm{RH}, 85{ }^{\circ} \mathrm{C} / 85 \% \mathrm{RH}$ 조건 에서 각각 $\mathrm{PID}$ 테스트를 진행한 결과, $\mathrm{EVA}$ 필름의 비 저항 차이가 PID에 상당한 영향을 미쳤다. 실험에 사용 된 High $-\rho \mathrm{EVA}$ 와 low $-\rho \mathrm{EVA}$ 의 비저항은 각각 $10^{15}$ $\Omega \cdot \mathrm{cm}, 6 \cdot 10^{14} \Omega \cdot \mathrm{cm}$ 이었으며, $60{ }^{\circ} \mathrm{C} / 85 \% \mathrm{RH}$ 조건 에서 $96 \mathrm{~h}$ 진행했을 때, high- $\mathrm{EVVA}$ 는 약 $0.8 \%$, low$\rho \mathrm{EVA}$ 는 약 $85 \%$ 출력 감소를 보였으며, $85{ }^{\circ} \mathrm{C} / 85 \%$ $\mathrm{RH}$ 조건에서는 각각 $9.2 \%, 96.6 \%$ 감소하였다. 연구 결 과를 통해 high- $\rho \mathrm{EVA}$ 는 가혹한 환경에서도 PID 방 지 효과를 보이지만 $85{ }^{\circ} \mathrm{C} / 85 \% \mathrm{RH}$ 테스트 조건에서 $5 \%$ 이하의 성능 저하를 목표로 하는 IEC 기준에는 부합 하지 않고 상용화된 $\mathrm{EVA}$ 보다 가격이 비싸다는 단점이 있다.

\section{3-1-2. 폴리올레핀|4,5,12,16)}

$\mathrm{EVA}$ 는 고온 다습한 환경에서 수분 침투에 의해 아세 트산을 생성하며, 낮은 안정성과 높은 투습도로 인해 대 체재로써 폴리올레핀(POE, Poly Olefin Elastomer)이 크게 주목받고 있다. $\mathrm{POE}$ 는 구성 물질에 초산 비닐이 함유하고 있지 않아 수분 침투 시 아세트산을 형성하지 않고 EVA 보다 낮은 수분 투과율을 가지며, 필름의 체 적 저항이 EVA보다 높아 누설 전류에 의한 PID 현상을 더 잘 견딜 수 있다. H. J. Son 등은 모듈 전 후면에서 반사되는 모든 빛을 흡수하여 발전량을 최대로 끌어내 기 위해 양면 발전 태양전지에 사용되는 투명 백시트와 $\mathrm{EVA}, \mathrm{POE}$ 등의 봉지재 사이의 열화 특성을 연구하였 다. $85{ }^{\circ} \mathrm{C} / 85 \% \mathrm{RH}$ 의 항온 항습 챔버에서 5000 시간 동 안 가속 시험을 진행했을 때, $\mathrm{POE} /$ 투명 백시트 구조보 다 $\mathrm{EVA} /$ 투명 백시트 구조에서 단파장 영역에서 장파장 영역까지 급격한 투과도 감소를 보였으며 그 결과 단락 전류 밀도가 감소하였다. 또 $\mathrm{EVA}$ 의 부식으로 인해 발생 


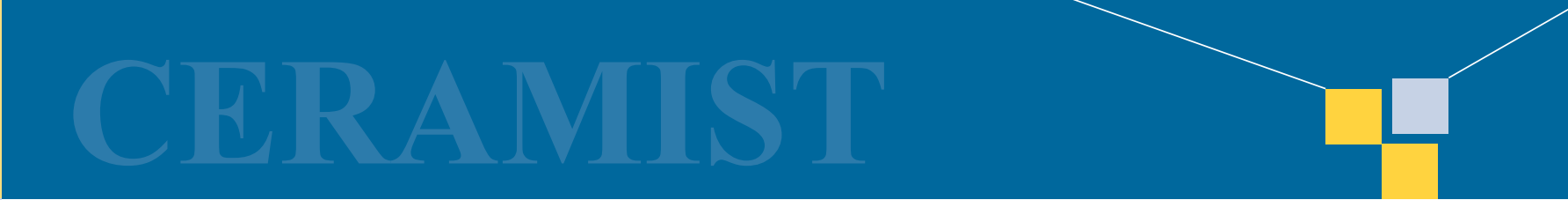

\section{특 집 표 정동욱, 장은진, 유상우}
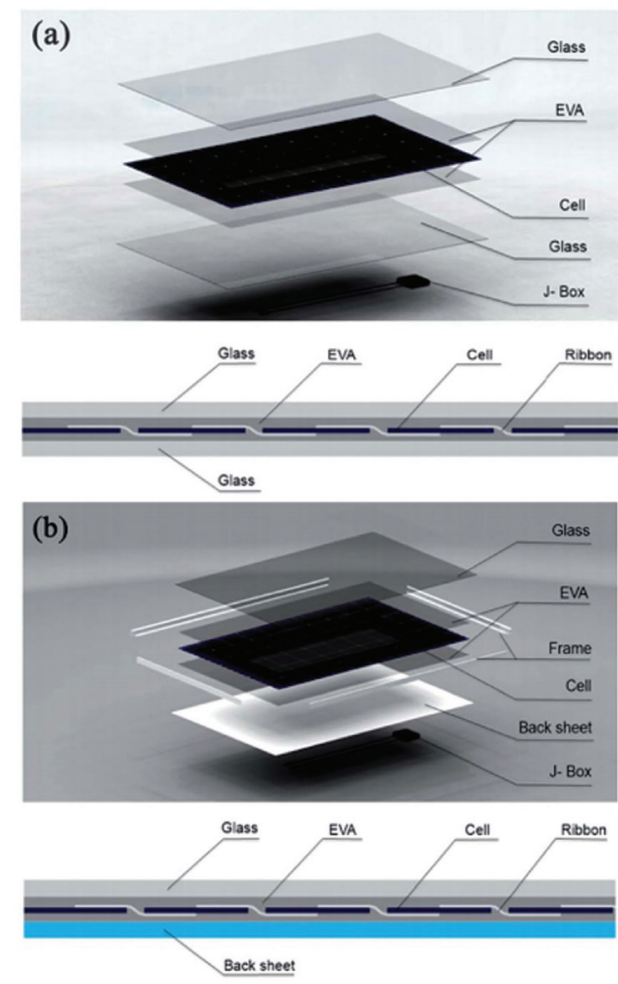

Fig. 3. 이중 유리 모듈 (a) 및 기존 모듈 (b)의 구조 ${ }^{17)}$

한 아세트산이 전극을 부식시켜 직렬 저항이 증가하고 fill factor $(\mathrm{FF})$ 가 감소하였다. 이처럼 $\mathrm{POE}$ 는 EVA보다 우수한 특성을 가졌지만, 가격이 비싸고 라미네이션 공 정 시 더 높은 온도와 시간이 필요한 한계가 있다.

\section{3-1-3. Glass-to-Glass 구존,17)}

백시트를 유리로 대체하여 태양전지 모듈의 전후면을 모두 유리 기판을 사용한 Glass-to-Glass $\left(\mathrm{G}-\mathrm{to}_{\mathrm{L}}-\mathrm{G}\right)$ 샌드위치 구조가 많이 연구되고 있으며, 그 구조를 Fig. 3 에 나타내었다. 유리 기판은 백시트에 비해 우수한 수 분 불침투성을 가지고 있기 때문에 이중 유리 모듈은 더 높은 신뢰성 및 내구성 나타낸다. Virtuani 등의 연구 결과에 따르면, 모듈 상하부에 유리 기판을 적용한 후 가장자리를 밀봉하고 $85{ }^{\circ} \mathrm{C} / 85 \% \mathrm{RH}$ 조건에서 $\mathrm{PID}$ 테 스트를 진행했을 때, 576 시간 후에 $4.9 \%$ 의 성능 저하 만을 나타냈다. Y. Zhang 역시 백시트 모듈과 이중 유 리 모듈의 성능 저하를 $85{ }^{\circ} \mathrm{C} / 85 \% \mathrm{RH}$ 시험을 통해 비
교 분석한 결과, 기존 백시트 모듈은 600 시간 동안 최 대 출력이 $13.3 \%$ 만큼 저하된 반면에, 이중 유리 모듈은 $2.27 \%$ 만큼만 감소됨을 보고하였다. 이는 하단 유리 기 판이 수분 유입을 줄여 PID 발생을 지연시켰기 때문이 다. 이중 유리 모듈의 사용은 습기와 다양한 스트레스 조건에서 우수한 성능을 나타내지만, 두께 및 무게가 증 가하고, 충격에 의한 파손위험이 있어 상용화하기에 어 려움이 있다.

\section{3-2. 세라믹 투습방지막}

\section{$3-2-1 . \mathrm{SnO}_{x}{ }^{18)}$}

박막 태양 전지 적용을 위한 TCGDB (Transparent and conductive gas diffusion barriers)는 전극 보 호 및 수분 침투 방지 역할을 수행하며, 저온 ALD 공정 을 통해 증착된 $\mathrm{SnO}_{\mathrm{x}}$ 는 뛰어난 성능의 $\mathrm{TCGDB}$ 이다. 투 습 방지 특성을 확인하기 위해 $85{ }^{\circ} \mathrm{C} / 85 \% \mathrm{RH}$ 조건에서 $\mathrm{Ca}$-test를 진행했을 때, $\mathrm{ZnO}$ 는 전도도가 2 일 내에 10 배 이상 감소한 반면, $\mathrm{SnO}_{\mathrm{x}}$ 는 50 일 이후에도 균일한 전 도도를 유지했고 $10^{-6} \mathrm{~g} / \mathrm{m}^{2} \cdot$ day의 매우 낮은 WVTR 값을 나타냈다고 보고되었다.

\section{3-2-2. $\mathrm{TiO}_{2}{ }^{19,20)}$}

수분 장벽 특성을 가진 다양한 물질 중 $\mathrm{TiO} 2$ 박막은 주변 대기에 포함된 산소와 습기에 대한 우수한 장벽 특 성을 나타내어 전자 장치의 수명이 향상된다고 알려져 있다. $\mathrm{ALD}$ 공정을 통해 $\mathrm{PET}$ 기판 위에 증착된 $60 \mathrm{~nm}$ $\mathrm{TiO}_{2}$ 확산 방지막은 $60{ }^{\circ} \mathrm{C} / 85 \% \mathrm{RH}$ 조건에서 $\mathrm{Ca}$-test 를 진행했을 때, $6 \times 10^{-4} \mathrm{~g} / \mathrm{m}^{2} \cdot$ day의 WVTR 값을 나 타냈다고 보고되었다.

\section{3-2-3. $\operatorname{SiN}_{x}^{21)}$}

최근 수분 침투에 의한 고분자 기판의 열화를 막는 투 명한 산화물층이 플렉서블 전자 장치 분야에 널리 적용 되고 있다. T. Y. Cho 등은 대량 생산에 유리한 무기 단 층 구조의 수분 장벽 개발에 중점을 두고 $\mathrm{SiN}_{\mathrm{x}}$ 의 광학 투과율과 WVTR 등에 대한 연구를 진행하였다. Roll- 
to-roll PECVD로 증착된 $\mathrm{SiNx}$ 층은 $\mathrm{NH}_{3} / \mathrm{SiH}_{4}$ 유속 비를 3으로 유지하였을 때, 막의 밀도가 가장 높았으며, $403 \mathrm{~nm}$ 두께의 $\mathrm{SiNx}$ 증착 후, $40{ }^{\circ} \mathrm{C} / 90 \% \mathrm{RH}$ 조건에 서 투습도를 측정했을 때, $1.67 \times 10^{-3} \mathrm{~g} / \mathrm{m}^{2} \cdot \mathrm{day}$ 의 우 수한 WVTR값을 나타냈다.

\section{3-2-4. $\mathrm{Al}_{2} \mathrm{O}_{3}^{9,22)}$}

$\mathrm{Al}_{2} \mathrm{O}_{3}$ 산화물 층은 높은 수분 불투과성 및 광학적 투 명성을 가지고 있으며 열과 기계적 스트레스에 대한 안 정성이 우수하기 때문에 수분 침투 방지막으로써 많 은 관심을 받아왔다. C-CVD (Cyclic chemical vapor deposition) 장비를 통해 $10 \mathrm{~nm}$ 두께의 $\mathrm{Al}_{2} \mathrm{O}_{3}$ 을 증착했 을 때, 필름은 $3.298 \mathrm{~g} / \mathrm{cm}^{3}$ 의 높은 밀도를 보였으며 투 습 경로를 제공할 수 있는 결정립계가 없는 비정질로 증 착되었다. 또한, $85{ }^{\circ} \mathrm{C} / 85 \% \mathrm{RH}$ 조건에서 $\mathrm{Ca}$-test를 진행했을 때 $1.51 \times 10^{-5} \mathrm{~g} / \mathrm{m}^{2}$ · day의 낮은 WVTR을 보 였다.

\section{3 $\mathrm{Al}_{2} \mathrm{O}_{3}$ 부식 방지}

$\mathrm{Al}_{2} \mathrm{O}_{3}$ 는 투습 방지 특성과 열 및 기계적 안정성이 우 수하고, 높은 광학 투명성으로 인해 매력적인 재료이 지만, 고온 다습한 환경에 노출될 경우 결정질로 상전 이 하면서 그 성능을 잃는 것으로 보고되었다. 따라서 $\mathrm{Al}_{2} \mathrm{O}_{3}$ 를 투습 방지막으로 사용하기 위해서는 부식을 방 지해야 하며, 이에 대해 다음과 같은 연구가 진행되었 다. ${ }^{6,23)}$

(1) $\mathrm{HfO}_{2}$ 는 결정입계와 공극이 수분 투과 경로를 제공 할 수 있는 문제가 있으나, $\mathrm{ALD}$ 를 통해 증착한 고 밀도의 $\mathrm{Al}_{2} \mathrm{O}_{3}$ 박막과 다층구조를 이룰 때, 서로의 약점이 보완되어 환경 안정성을 향상시키고 막질 이 치밀해져, 투습도를 감소시킬 수 있다고 보고되 었다. ${ }^{9}$

(2) $\mathrm{SiO}_{x}$ 박막의 경우 $\mathrm{Si}-\mathrm{O}-\mathrm{Si}$ 결합은 매우 강하기 때 문에 수산화하기 어렵고, 만약 $\mathrm{SiO}_{\mathrm{x}}$ 보호층이 용 해되더라도 후속 반응을 통해 다시 규산이 형성되 며, 이는 노출된 수산화된 알루미늄 산화물의 표 면과 역반응을 일으켜 결과적으로 $\mathrm{SiO}_{\mathrm{x}}$ 보호층이
재생성되기 때문에 효과적으로 $\mathrm{Al}_{2} \mathrm{O}_{3}$ 층을 보호할 수 있다고 보고되었다. ${ }^{23)}$ 또 $\mathrm{SiO}_{2}$ 층과 다층구조를 적용하면 $\mathrm{Al}_{2} \mathrm{O}_{3}$ 층의 pin-hole 결함을 덮어서 투 습도를 감소시킬 수 있지만, 층을 더 증가시킬 경 우 막의 취성 때문에 균열이 발생하여 오히려 투 습도가 증가하였다. ${ }^{24)}$

(3) $\mathrm{ZrO}_{2}$ 층과 $\mathrm{Al}_{2} \mathrm{O}_{3}$ 층을 다층구조로 적용하면 각 층 의 결정화를 억제할 수 있으며, 또 계면에서 알루 미네이트 상이 형성되어 구조적 치밀화를 통해 막 의 안정성이 향상되어 물에 의한 $\mathrm{Al}_{2} \mathrm{O}_{3}$ 의 부식을 방지할 수 있다고 보고되었다. ${ }^{25}$

다양한 산화물층이 $\mathrm{Al}_{2} \mathrm{O}_{3}$ 의 부식 방지에 효과가 있었 지만, 기본적으로 산화물층은 취성 문제가 발생하고, 특 히 ALD와 같은 느린 증착 공정을 이용해야 하는 문제가 있다. 반면, $\mathrm{Al}_{2} \mathrm{O}_{3}$ 층에서 발생 가능한 pin-hole, 이물 질 등의 문제점을 보완하기 위해 유기층에 대한 연구도 진행되고 있다. ${ }^{26)}$ 그 중에서도 Silane에 기반한 고분자 인 silamer (Silane-based inorganic/organic hybrid polymer)는 거친 기판을 평탄화하여 균일한 투습 방 지층이 형성되도록 하고, 가혹한 조건에서 $\mathrm{Al}_{2} \mathrm{O}_{3}$ 의 환 경 안정성을 향상시켜 부식을 방지하며, 경화과정 중에 $\mathrm{Al}_{2} \mathrm{O}_{3}$ 층과 반응하여 $\mathrm{Al}-\mathrm{Si}-\mathrm{O}$ 결합을 통해 pin-hole 결함을 제거할 수 있다고 보고되었다. ${ }^{8)}$

\section{4. 실험방법}

본 연구에서는 silamer와 $\mathrm{Al}_{2} \mathrm{O}_{3}$ 를 유무기 하이브리 드 코팅하고, 태양전지 백시트에 적용했을 때 유기층인 silamer의 효과와 투습 방지 특성을 분석해보고자 하였 다. $\mathrm{PE} / \mathrm{PET} / \mathrm{PET}$ 구조의 일반적인 태양전지용 백시트 (두께 $290 \mu \mathrm{m}$ )를 $5 \mathrm{~cm}^{2}$ 크기로 잘라 silamer와 $\mathrm{Al}_{2} \mathrm{O}_{3}$ 를 유무기 하이브리드 코팅하여 투습도를 분석하였다. $\mathrm{Al}_{2} \mathrm{O}_{3}$ 는 thermal atomic layer deposition (thermal $\mathrm{ALD}$ ) 장비를 통해 백시트 기판에 증착되었으며, 증착 조건은 Table 1.에 명시하였다. $85{ }^{\circ} \mathrm{C}$ 이상의 온도에서 는 $\mathrm{PET}$ 기판의 부식 발생한다고 알려져 있어 모든 공정 은 그보다 낮은 $70{ }^{\circ} \mathrm{C}$ 에서 진행하였다. ${ }^{11)}$ Precursor와 


\section{특 집 표 정동욱, 장은진, 유상우}

\begin{tabular}{|c|c|}
\hline \multicolumn{2}{|c|}{$\operatorname{ALD~} \mathrm{Al}_{2} \mathrm{O}_{3}(60 \mathrm{~nm})$} \\
\hline Substrate & $290 \mu \mathrm{m}$ Back sheet \\
\hline Reactant & $\mathrm{H}_{2} \mathrm{O}$ \\
\hline Metal source & Trimethylaluminum $\left[\mathrm{TMA}, \mathrm{Al}_{2}\left(\mathrm{CH}_{3}\right)_{6}\right]$ \\
\hline Temperature & $70{ }^{\circ} \mathrm{C}$ \\
\hline $\begin{array}{c}\mathbf{t}_{\mathrm{s} 1}, \mathbf{t}_{\mathrm{s} 2} \\
(\text { exposure time) }\end{array}$ & $0.2 \mathrm{~s}$ \\
\hline$\underset{\text { (purging time for Ar) }}{\mathbf{t}_{\mathrm{p} 1}, \mathbf{t}_{\mathrm{p2}}}$ & $30 \mathrm{~s}$ \\
\hline Ar flow rate & $80 \mathrm{sccm}$ \\
\hline Pressure & $4 \times 10^{-1}$ Torr \\
\hline Growth rate & $1.2 \AA /$ cycle \\
\hline
\end{tabular}

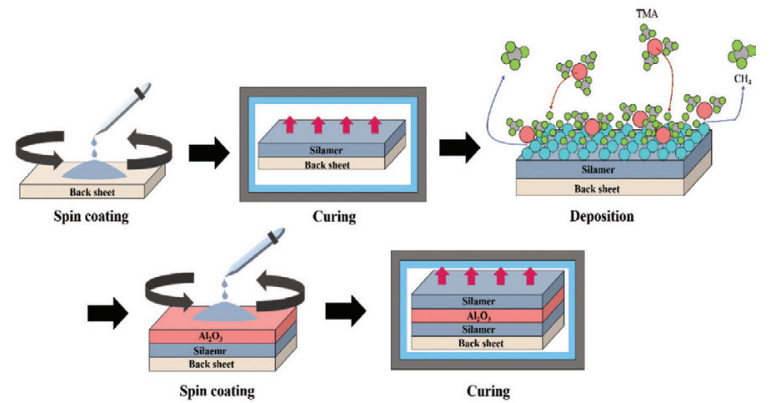

Fig. 4. 유무기 하이브리드 투습 방지막 증착 공정

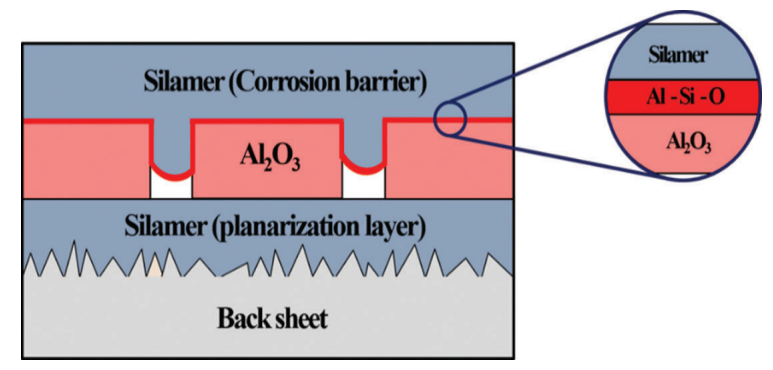

Fig. 5. 제작된 투습 방지막의 모식도

reactant는 각각 Trimethylaluminum (TMA)와 $\mathrm{H}_{2} \mathrm{O}$ 를 사용하였고, TMA와 reactant 노출시간은 0.2 초이 며, 소스 노출 후 남은 잔여물들을 배출하기 위해 아 르곤 가스를 $80 \mathrm{scccm}$ 흘려주어 30초간 퍼지하였다. 이 때 압력은 0.4 torr였고, 500 cycle 진행하여 약 60 $\mathrm{nm}$ 두께의 $\mathrm{Al}_{2} \mathrm{O}_{3}$ 층을 얻었다. 전체 샘플 제작 공정은 Fig. 4에 명시하였다. 유기층으로는 silamer (TB-30, Intech Nano-Materials)를 사용하였으며, 스핀코팅 방 법으로 코팅하였다. 코팅 조건은 $5000 \mathrm{rpm}$ 으로 30초간 가속한 후 3 초간 유지하였다. 코팅된 silamer 층은 진공 상태의 $\mathrm{ALD}$ 챔버에서 온도를 $70{ }^{\circ} \mathrm{C}$ 로 올려준 후 30 분 간 경화를 진행하였다.

증착된 구조의 표면 및 단면 이미지 분석을 위해 optical microscope (Metallurgical microscope me33, DAEMYUNG)와, scanning electron microscope (JSM-7610F PLUS, JEOL) 장비를 사용하였으며 투습 도는 MOCON (PERMATRAN-W Model 3/33) 장비를 이용해 $37.8{ }^{\circ} \mathrm{C} / 100 \% \mathrm{RH}$ 조건에서 72 시간 동안 측정 하였다.

\section{5. 실험 결과}

제조된 샘플의 모식도를 Fig. 5에 나타내었다. 첫 번 째 silamer층은 $\mathrm{Al}_{2} \mathrm{O}_{3}$ 층의 증착을 돕기 위해 표면을 평 탄화해주는 역할을 한다. 두 번째 층은 실질적으로 투습 방지역할을 수행하는 $\mathrm{Al}_{2} \mathrm{O}_{3}$ 이며, 마지막 3번째 silamer 층은 경화과정 동안 $\mathrm{Al}_{2} \mathrm{O}_{3}$ 층과 반응을 통해 $\mathrm{Al}-\mathrm{Si}-\mathrm{O}$ 

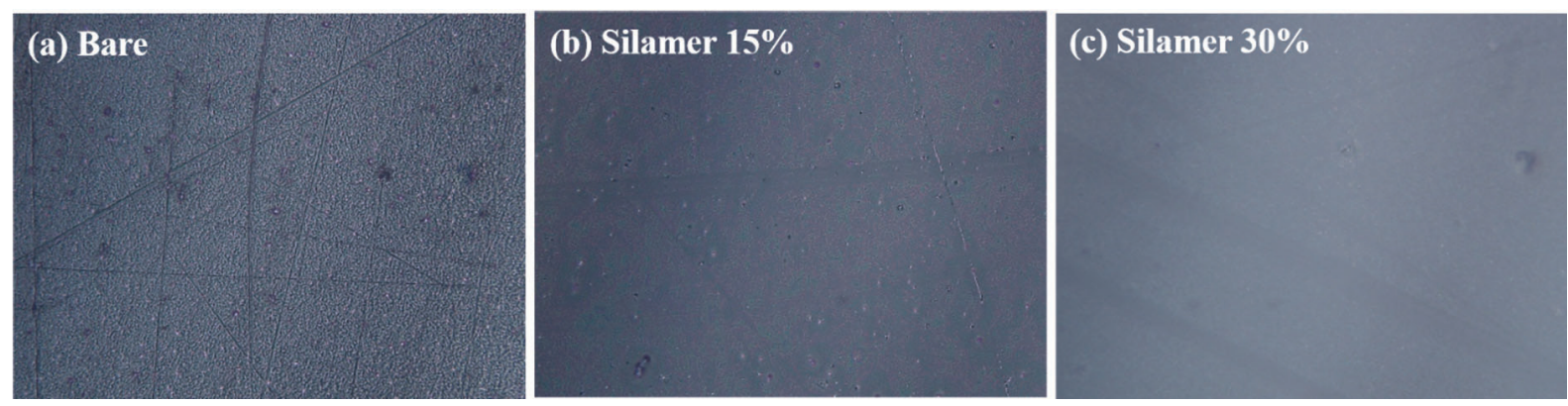

Fig. 6. 백시트 표면 광학현미경 이미지 (a) 코팅층이 없는 상태, (b) $15 \%$ 농도의 silamer 용액으로 코팅된 유기층, (c) $30 \%$ 농도의 silamer 용액으로 코팅된 유기층

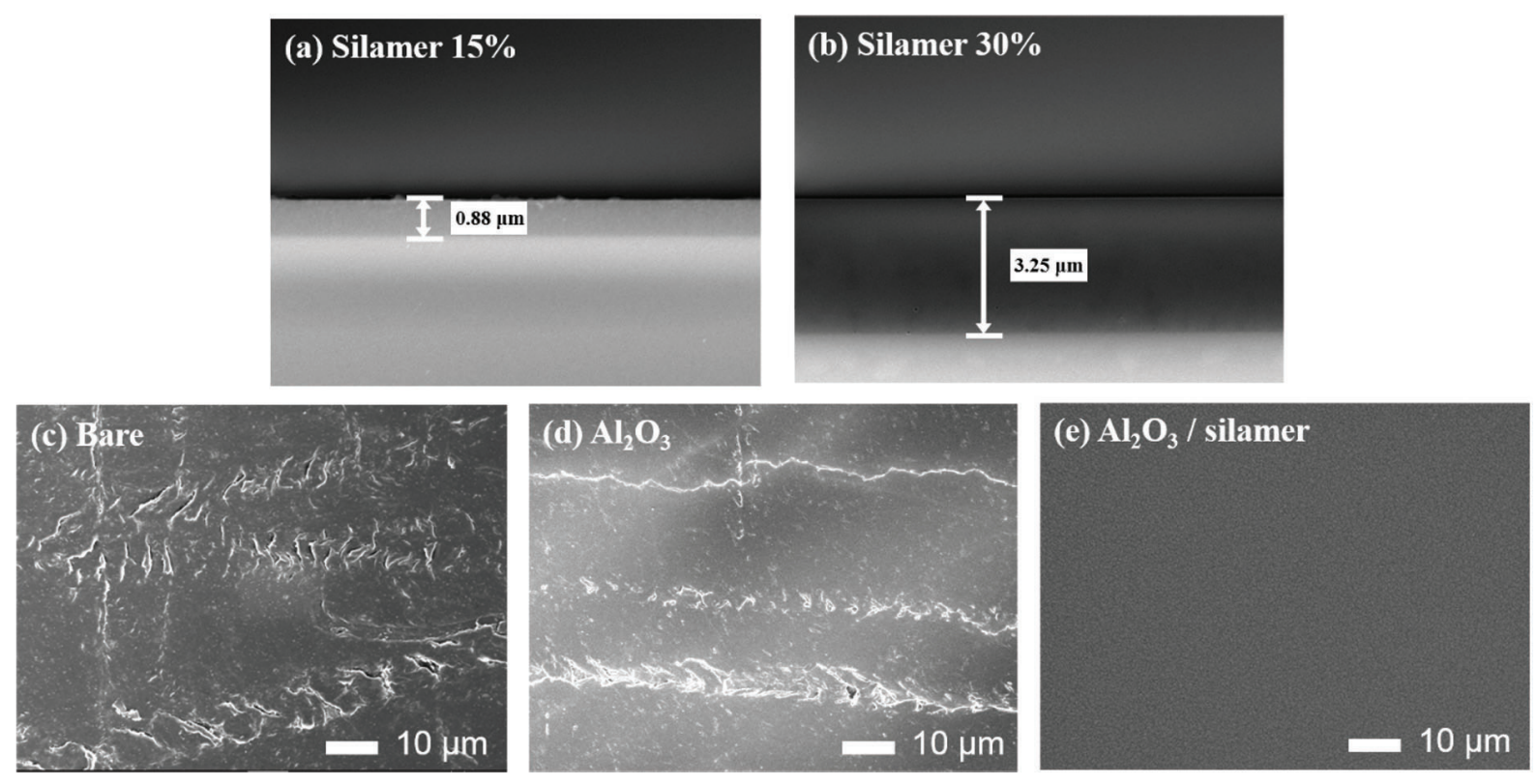

Fig. 7. 코팅 공정에 따른 백시트의 전자현미경 분석 결과. (a) $15 \%$ 농도의 silamer 코팅층 단면, (b) $30 \%$ 농도의 silamer 코팅층 단면, (c) 코팅층이 없는 상용 back-sheet 표면, (d) silamer 유기층 없이 증착된 $\mathrm{Al}_{2} \mathrm{O}_{3}$ 무기층 표면, (e) $30 \%$ 농도 silamer 코팅층 위에 $\mathrm{Al}_{2} \mathrm{O}_{3}$ 증착 공정 후의 표면

결합을 형성하고 $\mathrm{Al}_{2} \mathrm{O}_{3}$ 의 pin-hole 결함을 제거하며 환 경 안정성을 향상시킨다고 보고되었다. ${ }^{8}$

Silamer의 평탄화 효과를 확인하기 위해 광학현미 경 이미지를 분석하였다. Fig. 6 (a), (b)에 보이듯 기존 의 백시트의 표면에는 매우 많은 스크래치 및 입자들이 존재하며, silamer $15 \%$ 용액을 코팅했을 때, 평탄화 효 과는 있었지만, 큰 스크래치와 입자들을 덮지 못했다. 반면 더 농도가 높은 silamer $30 \%$ 용액을 사용했을 때 는 Fig. 6 (c)에 보이는 바와 같이 표면의 큰 스크래치
까지 덮어 평탄화됨을 확인할 수 있었다. 더 자세한 분 석을 위해 주사전자현미경을 이용해 분석한 표면 이미 지를 Fig. 7에 나타내었다. Fig. 7 (a), (b)는 실리콘 웨 이퍼 위에 silamer를 코팅했을 때의 단면 이미지이다. silamer 15\% 용액을 코팅했을 경우 두께는 약 $880 \mathrm{~nm}$ 였으며, Fig. 3 (b)로 미루어 볼 때 이 두께는 거친 백 시트의 표면을 평탄화 하기에는 부족한 두께로 생각된 다. 반면 표면의 큰 스크래치까지 평탄화할 수 있었던 silamer 30\% 용액을 사용했을 때의 두께는 약 $3.25 \mu \mathrm{m}$ 


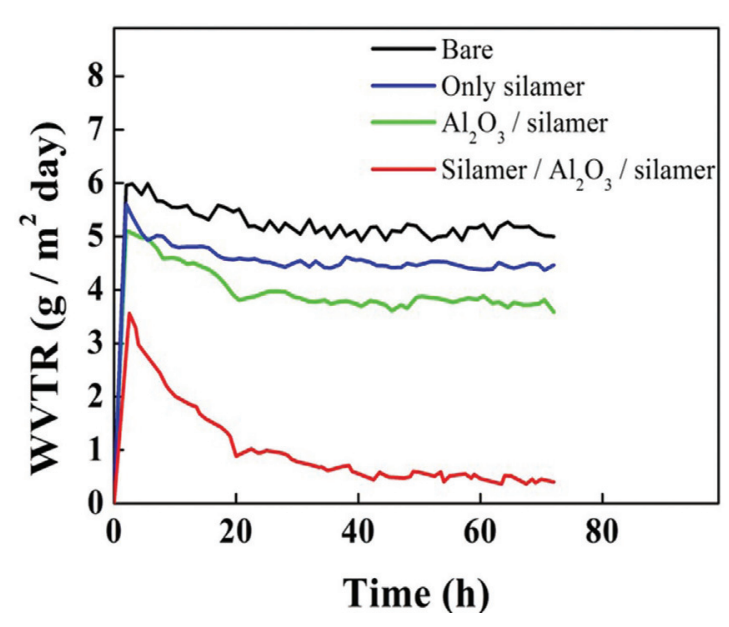

Fig. 8. 유무기 하이브리드 층 구조에 따른 투습도 측정 결과 비교

으로 측정되었다. Fig. 7 (c)-(e)는 백시트의 표면 이미 지이다. 마찬가지로 기존 백시트의 표면에는 매우 많은 스크래치가 존재했으며, 평탄화하지 않은 상태에서 그 대로 $\mathrm{Al}_{2} \mathrm{O}_{3}$ 를 증착하였을 때에는 표면의 스크래치를 따 라 증착된 $\mathrm{Al}_{2} \mathrm{O}_{3}$ 층에 크랙이 발생함을 알 수 있었다. 반 면 백시트 위에 silamer를 코팅하고 $\mathrm{Al}_{2} \mathrm{O}_{3}$ 를 증착하였 을 경우 표면에 스크래치를 발견할 수 없었으며, 이를 통해 silamer층이 효과적으로 백시트를 평탄화했음을 확인할 수 있었다.

위와 같은 방법으로 유무기 hybrid coating 층으로 보호된 백시트의 WVTR 값으로부터 투습도를 평가하 였다. $\mathrm{MOCON}$ 장비를 이용해 측정하였으며, 원리는 두 챔버 사이에 샘플을 고정시키고, 한 챔버에는 수분을 다 른 챔버에는 질소를 흘려주어 샘플을 투과한 수분이 질 소 속에 포함된 농도를 측정하는 방식이다. 측정은 37.8 ${ }^{\circ} \mathrm{C}$ 의 온도와 $100 \%$ 상대습도 조건에서 72 시간 동안 진 행하였으며, 결과를 Fig. 8에 나타내었다. 코팅을 하지 않은 기존 백시트의 경우 WVTR은 5.2로 측정되었고, silamer만 올린 샘플의 경우 WVTR 값은 약 4.7로 투습 도에 큰 차이를 보이지 않았으며, 이를 통해 silamer는 투습도에 큰 영향을 주지 않는다는 것을 확인할 수 있었 다. 또 $\mathrm{Al}_{2} \mathrm{O}_{3} /$ silamer 샘플과 silamer $/ \mathrm{Al}_{2} \mathrm{O}_{3} /$ silamer 샘플의 경우 WVTR 값은 각각 3.7과 0.36으로 후자의
경우가 더 낮은 투습도를 나타내었는데, 이는 경화과 정 중에 $\mathrm{Al}_{2} \mathrm{O}_{3}$ 와 silamer 사이에 $\mathrm{Al}-\mathrm{Si}-\mathrm{O}$ 결합이 형성 되어 pin-hole 결함이 제거되었기 때문으로 생각된다. Silamer와 $\mathrm{Al}_{2} \mathrm{O}_{3}$ 를 유무기 하이브리드 코팅함으로써 투 습도를 낮출 수 있었지만, 여전히 상당히 높은 투습도 값을 나타내었다. 이는 향후 추가연구를 통해 증착조건 및 두께를 최적화한다면, 투습도를 더 감소시킬 수 있을 것으로 생각되며, 또 고온, 다습한 환경에서 투습도 분 석을 진행할 경우 silamer의 환경 안정성 향상 효과까지 분석할 수 있을 것으로 생각되어 투습도 감소에 더 효과 적일 것으로 기대한다.

\section{7. 결론}

본 연구에서는 투습이 태양전지에 미치는 영향과, 투 습도를 낮출 수 있는 다양한 투습 방지막에 대해 알아보 고 실제로 적용해 보았다. 다양한 투습 방지막 중에서 $\mathrm{Al}_{2} \mathrm{O}_{3}$ 는 저렴하고 공정최적화가 잘되어 있으며, 우수한 투습 방지 특성을 지닌 것으로 알려져 있으나, 고온 다 습한 환경에서 상전이가 발생하여 투습 방지 특성을 잃 는 문제가 발생한다. 따라서 $\mathrm{Al}_{2} \mathrm{O}_{3}$ 의 부식을 막기 위해 silane 기반의 폴리머인 silamer를 이용해 유무기 하이 브리드 코팅을 적용하였다. Silamer로 인한 평탄화 효 과가 입증되었고, silamer $/ \mathrm{Al}_{2} \mathrm{O}_{3} /$ silamer 3 중층 구조에 서 WVTR이 0.36으로 가장 낮았다. 상부 silamer 층의 경화 과정 중에 $\mathrm{Al}-\mathrm{Si}-\mathrm{O}$ 결합이 형성되어 pin-hole 결 함이 제거되었기 때문으로 생각된다. 본 연구에서 제조 된 유무기 하이브리드 투습 방지막의 WVTR의 경우 상 용 결정질 실리콘 태양전지 모듈에 적용되기에 충분한 수치이지만, 향후 추가적인 공정 최적화가 진행된다면 페로브스카이트 태양전지 등 기타 다른 전자소자의 투 습 방지막으로서도 활용될 수 있을 것으로 기대한다.

\section{사사}

본 연구는 산업통상자원부(MOTIE)와 한국에너지기 술 평가원(KETEP)의 지원을 받아 수행되었음. (No. 


\section{0)}

This work was supported by the Korea Institute of Energy Technology Evaluation and Planning (KETEP) and the Ministry of Trade, Industry \& Energy (MOTIE) of the Republic of Korea (No. 20183010014320).

*These authors equally contributed to this article.

\section{REFERENCES}

1. Egan, M. Shining times for clean energy ahead? 'Vibe in solar industry is great and getting greater. WRALTechWire (Nov 14, 2020). https://www. wraltechwire.com/2020/11/14/shining-times-for-cleanenergy-ahead-vibe-in-solar-industry-is-great-andgetting-greater/

2. Bae, S. et al. Potential induced degradation(PID) of crystalline silicon solar modules. Korean J. Mater. Res. 24, 326-337 (2014).

3. Kim, J. H. Outdor Testing and Degradation of EVA and POE Encapsulated Photovoltaic Modules. J. Korean Inst. Electr. Electron. Mater. 29, 847-852 (2016).

4. Park, E. B. et al. A Study on the Fabrication and Characteristics of Snow Removal PV Module \& System using Heating Film. Curr. Photovolt. Res. 4, 159-163 (2016).

5. Jin, H., Sung, S. \& Kim, H. Degradation Characteristics according to Encapsulant Materials Combining with Transparent Backsheet on the Mini Shingled Si Photovoltaic Modules. 8, 12-16 (2020).

6. Jeong, E. G., Jeon, Y., Cho, S. H. \& Choi, K. C. Textilebased washable polymer solar cells for optoelectronic modules: Toward self-powered smart clothing. Energy Environ. Sci. 12, 1878-1889 (2019).

7. Dokmai, V., Methaapanon, R. \& Pavarajarn, V. Corrosion of amorphous alumina in deionized water under mild condition. Appl. Surf. Sci. 499, 143906 (2020).

8. Kwon, J. H. et al. Design of Highly Water Resistant, Impermeable, and Flexible Thin-Film Encapsulation Based on Inorganic/Organic Hybrid Layers. ACS Appl. Mater. Interfaces 11, 3251-3261 (2019).

9. Kim, L. H. et al. Highly-impermeable $\mathrm{Al} 2 \mathrm{O} 3 / \mathrm{HfO} 2$ moisture barrier films grown by low-temperature plasma-enhanced atomic layer deposition. Org. Electron. 50, 296-303 (2017).

10. Kim, J.-Y., Kim, J.-H., Chan, S.-I., Lim, D.-G. \& Kim, Y.-S. A Review on the Failure Mechanism for Crystalline Silicon PV Module. J. Korean Inst. Electr. Electron. Mater. Eng. 27, 343-349 (2014).

11. Omazic, A. et al. Relation between degradation of polymeric components in crystalline silicon PV module and climatic conditions: A literature review. Sol. Energy Mater. Sol. Cells 192, 123-133 (2019).

12. Kim, S. H., Choi, J. J., Kim, S. C., Chun, S. I., Park, N. C. The study of outdoor test and effect of solubility of encapsulants on the relative humidity at the interface between encapsulant and cell surface for crystalline silicon PV Module. Korean, T. \& Energy, S. (2012).

13. Oliveira, M. C. C. de, Diniz Cardoso, A. S. A., Viana, M. M. \& Lins, V. de F. C. The causes and effects of degradation of encapsulant ethylene vinyl acetate copolymer (EVA) in crystalline silicon photovoltaic modules: A review. Renew. Sustain. Energy Rev. 81, 2299-2317 (2018).

14. Oreski, G., Mihaljevic, A., Voronko, Y. \& Eder, G. C. Acetic acid permeation through photovoltaic backsheets: Influence of the composition on the permeation rate. Polym. Test. 60, 374-380 (2017).

15. Virtuani, A., Annigoni, E. \& Ballif, C. One-typefits-all-systems: Strategies for preventing potentialinduced degradation in crystalline silicon solar photovoltaic modules. Prog. Photovoltaics Res. Appl. 27, 13-21 (2019).

16. Byeong-man, K. I. M. et al. A Study on manufacturing process of PV Module according to Back sheet type. (2010).

17. Zhang, Y. et al. Long-term reliability of silicon waferbased traditional backsheet modules and double glass modules. RSC Adv. 5, 65768-65774 (2015).

18. Behrendt, A. et al. Highly Robust Transparent and Conductive Gas Diffusion Barriers Based on Tin Oxide. Adv. Mater. 27, 5961-5967 (2015).

19. Park, S. et al. Reduced water vapor transmission rates of low-temperature-processed and sol-gel-derived titanium oxide thin films on flexible substrates. Org. Electron. 36, 133-139 (2016).

20. Seo, S. W., Jung, E., Lim, C., Chae, H. \& Cho, S. 


\section{특 집 ㅁㅁ정동욱, 장은진, 유상우}

M. Moisture permeation through ultrathin Tio 2 films grown by atomic layer deposition. Appl. Phys. Express 5, (2012).

21. Cho, T. Y. et al. Moisture barrier and bending properties of silicon nitride films prepared by roll-to-roll plasma enhanced chemical vapor deposition. Thin Solid Films 660, 101-107 (2018).

22. Park, C. Y., An, J. S., Jang, H. J., Lee, J. H. \& Choi, B. H. Growth behavior and improved water-vaporpermeation-barrier properties of 10-nm-thick single Al2O3 layer grown via cyclic chemical vapor deposition on organic light-emitting diodes. Org. Electron. 15, 1717-1723 (2014).

23. Rückerl, A. et al. Characterization and prevention of humidity related degradation of atomic layer deposited Al2O3. J. Appl. Phys. 121, (2017).

24. Dameron, A. A. et al. Gas diffusion barriers on polymers using multilayers fabricated by $\mathrm{Al} 2 \mathrm{O} 3$ and rapid $\mathrm{SiO} 2$ atomic layer deposition. J. Phys. Chem. C 112, 4573-4580 (2008).

25. Meyer, J., Schmidt, H., Kowalsky, W., Riedl, T. \& Kahn, A. The origin of low water vapor transmission rates through $\mathrm{Al} 2 \mathrm{O} 3$ / $\mathrm{ZrO} 2$ nanolaminate gasdiffusion barriers grown by atomic layer deposition. Appl. Phys. Lett. 96, 94-97 (2010).

26. Korean, T. \& Society, C. Flexible Organic Light-Emitting Display Development Trend. J. Korean Ceram. Soc. (2018). 